\title{
The Appraisal Right in terms of Section 164 of the Companies Act 71 of 2008: An Overview
}

M Phakeng*

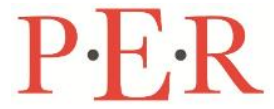

Pioneer in peer-reviewed, open access online law publications

\section{Author}

Madimetja Phakeng

Affiliation

Advocate, South Africa

Email

madimetjaphakeng@yahoo.com

Date Submission

14 May 2020

Date Revised

24 November 2021

Date Accepted

24 November 2021

Date published

17 January 2022

\section{Editor Prof W Erlank}

How to cite this article

Phakeng M "The Appraisal Right in terms of Section 164 of the Companies Act 71 of 2008: An Overview" PER / PELJ 2022(25) DOI

http://dx.doi.org/10.17159/17273781/2022/v25i0a8332

\section{Copyright}

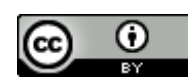

DOI

http://dx.doi.org/10.17159/1727-

3781/2022/v25i0a8332

\section{Abstract}

The appraisal right in terms of section 164 of the Companies Act 71 of 2008 has been applicable to fundamental transactions undertaken by companies for a number of years. The first two aims of this article are first to provide an overview of the appraisal right, and second to revisit certain concerns that were raised about the determination of fair value by the courts where a shareholder makes an application to court for a determination of fair value. It is suggested that this should not present a major problem in practice, considering that existing practice in takeover laws requires the valuation of shares by an independent expert when a company undertakes an affected transaction. In the main, the requirements for fundamental transactions overlap with those for affected transactions. The requirements for affected transactions adequately deal with the determination of fair value. The third aim is to provide an overview of how companies attempt to limit the effect of the appraisal right on fundamental transactions using various terms and conditions precedents, and the fourth is to discuss developments in case law on the appraisal right remedy. It is concluded that the decisions of the courts on its application will assist companies in structuring fundamental transactions and shareholders in exercising the appraisal right. Finally, the article suggests reasons for including certain subsections in the appraisal right remedy, for instance, the power of the courts to award costs in certain respects and a requirement that extends the time periods within which a shareholder may make a demand where the company fails to comply with specific requirements. It is suggested that this enhances the ability of shareholders to exercise the appraisal right. The article also provides concluding remarks advising companies and shareholders. In the case of companies, it concludes, for instance, that due diligence in identifying the risk that certain shareholders may raise appraisal rights is required before initiating a transaction that may be subject to appraisal rights. Failure to do so may be costly to the company. And, in the case of shareholders, failure to adhere to the required procedures may result in loss of their appraisal right remedy, or loss of the right to approach the courts for an appropriate relief under the appraisal right remedy.

\section{Keywords}

Appraisal right; section 164 of the Companies Act 2008; procedural requirements; fundamental transactions; affected transactions; dissenting shareholders; fair value; independent expert; developing case law. 
[T]akeover law is an intensely practical topic. ${ }^{1}$

\section{Introduction}

The Companies Act 71 of 2008 (the Act) strengthened several provisions relating to shareholder rights and introduced new provisions to protect minority shareholders. Section 164, dealing with the appraisal right is one of the introductions. The right has featured in US corporate law for over a century. ${ }^{2}$ It now also forms part of the corporate laws of Canada and New Zealand. ${ }^{3}$ The right allows a shareholder to demand that a company buy back all shares held by that shareholder in the company and pay the shareholder the fair value of those shares instead of the value placed thereon for purposes of the transaction. This becomes applicable when a company undertakes specified transactions. The court may determine the value, but the process is not court-driven. ${ }^{4}$ Some of the important principles that the right supports are that it is an exit mechanism from the investee company for a dissenting shareholder, ${ }^{5}$ that it is a vital remedy for a potential unfairness, ${ }^{6}$ and that it serves to deter or restrain directors from taking bad business judgments. ${ }^{7}$

In essence, the right gives a shareholder who does not support the transaction a choice to exit an investment from the company in exchange for payment in cash by the company to acquire the investee shares. The scheme and purpose of section 164 is to give a shareholder who does not support a resolution to adopt a fundamental transaction the right to opt out of the consequences of that transaction even though the majority of shareholders voted in favour of the transaction. ${ }^{8}$ In the matter of Standard Bank Nominees, the court pointed out that:

[T] he section balances two interests: on the one hand, the right of the dissenting shareholder to opt out of the scheme of arrangement by exiting its shareholding,

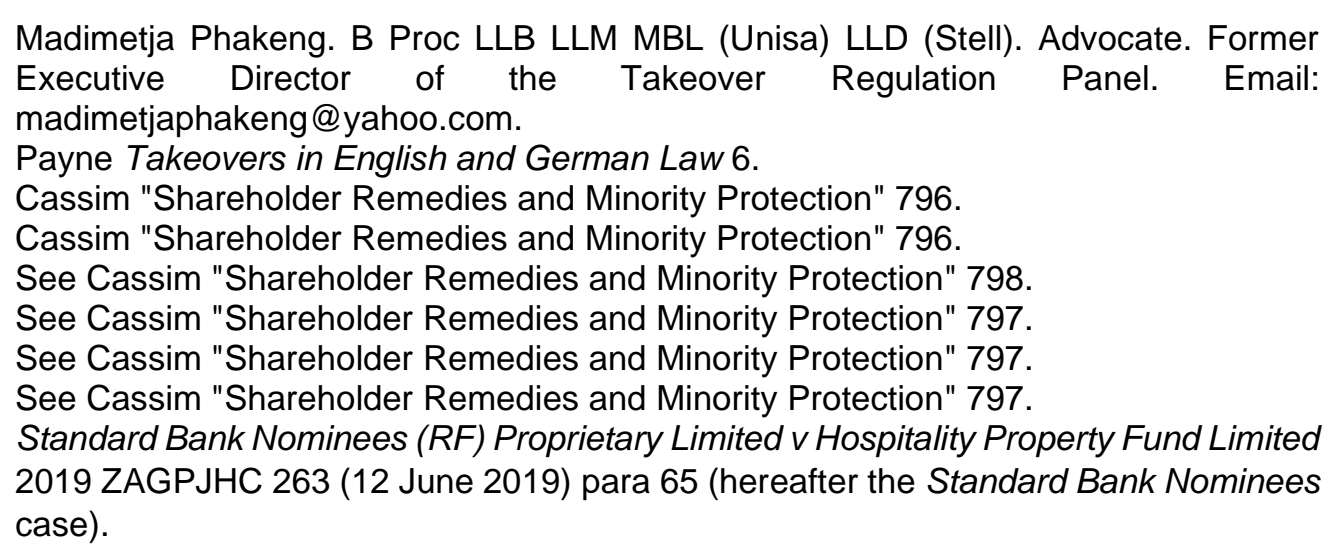


and on the other hand, the interests of the company to implement the scheme that enjoyed the support of the majority of shareholders. ${ }^{9}$

Some researchers have indicated that the appraisal right process under the section is complex. The section has "a daunting list of strict and rather technical hurdles which a shareholder is expected to clear". ${ }^{10}$ Davids et a ${ }^{11}$ also indicate that "the process is a potentially complicated, costly and timeconsuming one". However, it is also stated that it is comparable to similar provisions in other countries. ${ }^{12}$ The courts have also recognised the difficulty and complexity of exercising the appraisal right remedy. The court in Loest $v$ Gendac (Pty) $L t d^{13}$ stated that the procedural requirements are cumbersome. ${ }^{14}$ And, in the Standard Bank Nominees matter, the court pointed out that the provisions of the section inherently lack clarity. ${ }^{15}$

Because of these complexities and technicalities, companies and shareholders face challenges when the section has to be implemented. ${ }^{16}$ The increasing number of court decisions on the interpretation and application of the section will go a long way in assisting dissenting shareholders ("dissentients") to exercise the right and enhance the protection of shareholders in general. Companies seeking to undertake fundamental transactions will be forced to consider the courts' decisions. Similarly, such interpretations will create certainty and assist companies and their advisers in structuring and implementing fundamental transactions. While court decisions on the interpretation of the right may be slowly increasing, it will be some time before clarity, and a pattern emerges on its application. This is in part due to the complexity of the section and the few and varied fundamental transactions that have been challenged by minority shareholders and have eventually come before the courts.

A section 164 appraisal right arises in specific circumstances, mainly when a company undertakes a fundamental transaction, ${ }^{17}$ which transaction may also constitute an affected transaction as defined in terms of section 117(1)(c)

Standard Bank Nominees para 65.

Yeats 2014 Stell LR 335.

Davids, Norwitz and Yuill 2010 Acta Juridica 360.

See Yeats Effective and Proper Exercise of Appraisal Rights 190.

Loest v Gendac (Pty) Ltd 2017 ZAGPPHC 73 (3 March 2017) (hereafter the Loest case).

$14 \quad$ Loest para 20.

15 See Standard Bank Nominees para 6. The court in para 2 also indicates that the commentators have raised concerns about the complexity and technicalities of the mechanism.

$16 \quad$ Standard Bank Nominees para 2.

17 See Ch 5, Part A of the Companies Act 71 of 2008 (the Act), dealing with Fundamental Transactions. 
of the Act. ${ }^{18}$ The schemes of arrangement involving regulated companies and their shareholders are a common occurrence and a commercial reality. ${ }^{19}$ This article proceeds to consider appraisal rights that involve regulated companies. ${ }^{20}$

\section{The appraisal right: an overview}

\subsection{The steps}

Section 164(1) provides that the appraisal right remedy is not available in a case where a company is under a business rescue plan that was approved by shareholders under section 152 . The right is available and triggered under the following circumstances:

(i) the shareholders of a company approve a resolution that will: amend the company's memorandum of incorporation by altering preferences, rights, limitations or other terms of any class of shares which will have a materially adverse effect on the rights or interests of the holders of that class of shares; ${ }^{21}$ or

18 See Ch 5, Part B and C of the Act, read with the Takeover Regulations in Ch 5 of the Companies Regulations, 2011 (GN R351 in GG 34239 of 26 April 2011), dealing with the regulation of Affected Transactions as defined in $\mathrm{S}$ 117(1)(c). Luiz PELJ 2012105.

20 Section 117(1)(i) of the Act defines a regulated company as a company to which this Part, Part $\mathrm{C}$ and the Takeover Regulations apply, as determined in accordance with $\mathrm{s}$ 118(1) and (2). S 118(1) in turn determines that: "(1) Subject to subsections (2) to (4), this Part, Part $C$ and the Takeover Regulations apply with respect to an affected transaction or offer involving a profit company or its securities if the company is- (a) a public company; (b) a state-owned company, except to the extent that any such company has been exempted in terms of section 9; or (c) a private company, but only if- (i) the percentage of the issued securities of that company that have been transferred, other than by transfer between or among related or inter-related persons, within the period of 24 months immediately before the date of a particular affected transaction or offer exceeds the percentage prescribed in terms of subsection (2); or (ii) the Memorandum of Incorporation of that company expressly provides that the company and its securities are subject to this Part, Part $\mathrm{C}$ and the Takeover Regulations, irrespective of whether the company falls within the criteria set out in subparagraph (i). (2) The Minister, after consulting the Panel, may prescribe a minimum percentage, being not less than $10 \%$, of the issued securities of a private company which, if transferred within a 24-month period as contemplated in subsection (1)(c)(i), would bring that company and its securities within the application of this Part, Part C, and the Takeover Regulations in terms of that subsection. Based on the above criteria, all companies listed on a stock exchange that undertake fundamental transactions will be regulated companies." 
(ii) enter into the following transactions:

- a proposal in terms of section 112 to dispose of all or a greater part of the assets or undertaking of the company;

- $\quad$ a proposal in terms of section 113 to amalgamate or merge with another company; or

- $\quad$ a proposal in terms of section 114 for a scheme of arrangement; ${ }^{22}$ and

(iii) the dissentient has complied with the following:

- submitted a written notice to the company objecting to the resolution before the relevant resolution has been voted on;23

- $\quad$ voted against the adoption of the relevant resolution and complied with the procedural requirements; ${ }^{24}$

- $\quad$ and the shareholders have approved the relevant resolution. ${ }^{25}$

Where the company fails to warn shareholders about the proposed meeting or failed to advise the shareholders of their appraisal right under the section, the shareholder does not have to comply with the requirements of section 164(5), which includes sending a notice of objection to the resolution. A shareholder who meets the requirements of section 164(5) may demand the payment of the fair value of the shares within the required time periods. ${ }^{26}$ After the shareholders have approved the relevant resolution, the following further procedures are required:

(i) the company must send a notice to the dissentient to inform him/her that the relevant resolution has been approved within ten business days after such approval, unless the dissentient withdrew the notice of opposition or voted in favour of the resolution; 27

(ii) a dissentient who complied with the initial steps under section 164(5) may then submit a written notice to the company demanding that the company repurchase the relevant shares in the company, within 20

Section 164(2)(b) of the Act.

Section 164(3) of the Act.

Section 164(5)(c) of the Act.

Section 164(5)(b) of the Act.

Section 164(7) of the Act.

Section 164(4) of the Act. 
business days after the dissentient receives notice that the relevant resolution has been approved, or within 20 days after the day the shareholder becomes aware that the relevant resolution was adopted;

(iii) the dissentient's demand must be delivered to the TRP and must state:

- $\quad$ the name and address of the shareholder;

- the number and class of shares in respect of which the shareholder seeks payment; and

- a demand for payment of the fair value of those shares.

The implications of such a demand by a shareholder on the shareholder's rights are important, have been the subject of litigation, and are discussed beneath under case law. ${ }^{28}$ In terms of section 164(9) a shareholder who has sent a demand has no further rights in respect of those shares, other than to be paid their fair value, unless: (a) the shareholder withdraws that demand before the company makes an offer or allows an offer made by the company to lapse; (b) the company fails to make an offer, and the shareholder withdraws the demand; or (c) the company, by a subsequent special resolution, revokes the adopted resolution that gave rise to the shareholder's rights under this section. A dissentient shareholder's rights are reinstated without interruption if the demand is withdrawn before an offer is made or the offer lapses, the company fails to make an offer, or the company revokes the adopted resolution that triggered the appraisal right. ${ }^{29}$ The rights of a shareholder will be referred to further below when dealing with case law.

Once the dissentient has submitted the demand, the company will be obliged to submit a written offer to the dissentient to pay a fair value, the offer being accompanied by a statement indicating how the value of the shares was calculated. ${ }^{30}$ The offer to the dissentient must be on the same terms for all the shares held. ${ }^{31}$ The offer must be made within five business days after the later of:

(i) the day on which the action approved by the relevant resolution becomes effective;

\footnotetext{
See Standard Bank Nominees.

Section 164(10) of the Act.

Section 164(11) of the Act.

Section 164(12) of the Act.
} 
(ii) the last day on which the dissentient may submit the demand to the company; and

(iii) the day on which the company received the demand in cases where the company did not inform the dissentient that the relevant transaction was approved. 32

The requirement in (iii) is intended to ensure that a dissentient's rights are not prejudiced by a failure of the company to keep the dissentient informed about the state of the proposed transaction. Accordingly, the time periods to submit a demand may be extended to accommodate those situations where the dissentient was not aware of the proposed transaction through no fault of his/her own.

The next step after the company makes an offer dependends on the attitude of the dissentient to the offer made: is it a fairly valued offer? The dissentient must make a decision within 30 business days of receipt of the offer. The offer lapses if not accepted within this period. ${ }^{33}$ The dissentient wishing to accept the offer must then tender the relevant share certificates to the company, in the case of shares held through share certificates, or direct the authorised transfer agent to transfer the shares to the company, in the case of uncertificated shares. ${ }^{34}$ The company must then pay the agreed amount within 10 days of receiving the relevant share certificates, or transfer instructions where uncertificated shares are involved. ${ }^{35}$

\subsection{Court application}

A dissentient who demanded the payment of fair value from the company in accordance with the requirements of section 164 may apply to court for a determination by the court of a fair value of the shares and that the company pay the fair value so decided by the court, where the company has:

(i) failed to make an offer; or

(ii) made an offer that the dissentient believes to be inadequate, which offer has not lapsed. ${ }^{36}$

Section 164(11) of the Act.

Section 164(12) of the Act.

Section 164(13)(a) of the Act.

Section 164(13)(b) of the Act.

Section 164(14) of the Act. 
The court application must include shareholders who have not accepted the offer and are bound by the court decision, ${ }^{37}$ and the company must inform the shareholders of their right to participate in such an application, the date, place and consequences of the application. ${ }^{38}$ The court may determine whether any dissentient should be joined to the application. ${ }^{39}$ Under section 164(15)(c)(ii), the court must determine the fair value of all the shares of the dissentients. The court may, in its discretion, appoint one or more appraisers to assist in determining the fair value of the shares or award reasonable interest on the amount payable to a dissenting shareholder. ${ }^{40}$ This is intended to compensate the dissentient for the time value of money as there may be considerable delay before the shareholder receives the fair value payment. This should also serve as a deterrent for any delaying tactics on the part of companies. Under section 164(15)(v)(aa), the court must order the dissentients to comply with section 164(13)(a) (dealing with the tender and transfer of the relevant shares by the dissentient to be able to accept the offer made by the company) ${ }^{41}$ or withdraw their respective demands to be paid fair value (in which case the dissentient will rely on the court determination of fair value). It is notable that under section 164(15A) a dissentient can accept the offer from the company before the court orders the dissentient to withdraw his/her demand to be paid fair value, or order the dissentient to tender and transfer the relevant shares under section 164(13)(a). Section 164(15A) seems to provide flexibility to dissentients and is an attempt to encourage settlements of disputes before courts make decisions on their behalf. However, it is arguable that the court's broad discretion produces legal uncertainty, leading to the dissatisfied shareholders shying away from this exit option.

The fact is that even though the offer is inadequate, it must not have lapsed when a dissentient approaches the courts. Section 164(14)(b) prevents dissentients from approaching the court to determine the fair value of the shares after the offer has lapsed. This presents another challenge to a dissentient, who needs to ensure that that the timelines set in the Act are adhered to. This may be a challenge, considering that the dissentient must accept the offer within 30 business days after it is made. ${ }^{42}$ Therefore,

Section 164(15)(a) of the Act.

Section 164(15)(b) of the Act.

Section 164(15)(c)(i) of the Act.

Section 164(15)(c)(iii) of the Act.

See s 164(12) read with s 164(11) of the Act providing for the time period within which the company must make an offer to pay the dissentient what the company considers to be fair value.

42

See s 164(12) of the Act. 
dissentients should ensure that they have all the relevant information, particularly the fair value of the shares, at an early stage to be able to judge whether it would be beneficial to launch an application for the court to determine fair value for those shares.

\section{Concerns about the determination of fair value}

A common concern about the determination of a fair value by the courts is that the Act does not provide any guidance as to how the fair value of the shares should be determined. It is asserted that there is a wide range of valuation methodologies that may yield different results. It has also been pointed out that there are precedents to how the courts should deal with valuations. ${ }^{43}$ However, it is suggested that such precedents cannot be blindly followed but must be selected carefully to ensure an appropriate application in the unique context of appraisal rights. ${ }^{44}$ The issues raised on valuations during appraisal should not be a significant problem as accounting practices have well-established valuation methodologies to determine fair value. The method prescribed in the regulations ensures that a valuation is arrived at after rigorous procedures are followed, and an explanation is required justifying each method. ${ }^{45}$ Notably, regulation $90(6)(\mathrm{f})$ acknowledges that a valuation may result in a range of values by providing, among other provisions, that the expert in his valuation report must include "a range of final valuation values attributable to the relevant securities or assets and a most likely value used as the core number for purposes of the expression of the opinion". 46 An example of the common way of disclosing such valuation ranges is as follows: "In undertaking the valuation exercise above, we have determined a valuation range of ZAR 102 to ZAR 112 per Pioneer Foods Ordinary Share". ${ }^{47}$ A typical valuation report suggests that the expert has undertaken several steps to comply with the Act, the regulations and in certain instances, the JSE Listings Requirements. ${ }^{48}$

Section 164 states explicitly that the "written offer to pay an amount considered by company's directors to be the fair value of the relevant

\footnotetext{
$43 \quad$ Yeats Effective and Proper Exercise of Appraisal Rights 174.

44 See Yeats Effective and Proper Exercise of Appraisal Rights 174.

45 See reg 90 in GN R351 in GG 34239 of 26 April 2011, commonly referred to as the Companies Regulations, 2011 (hereafter the Regulations).

46 See reg $90(6)(f)$ of the Regulations.

47 Pioneer Food Group 2019 https://pioneerfoods.co.za/2019/08/29/2430/ 62.

48 Where a transaction relates to a company listed on the JSE Limited, such a transaction must comply with the requirements of both regulators - the TRP and JSE Limited. See Pioneer Food Group 2019 https://pioneerfoods.co.za/2019/08/29/2430/ Annexure 1.
} 
shares...". ${ }^{49}$ In practice, directors will rely on the opinion of the independent expert appointed in terms of section 114(2) read with section 114(3) and regulation 90 (commonly referred to as a fairness opinion), in cases where the transaction also constitutes an affected transaction in terms of section $117(1)$ (c) of the Act, ${ }^{50}$ as to what is the fair value of the relevant shares. ${ }^{51}$ The offer made in terms of section 164(11) must be in line with the determination by the directors. ${ }^{52}$ Directors must seek an expert report required for a section 114 transaction. ${ }^{53}$ The valuation methods prescribed by the Act and the regulations are robust enough to cater for the valuation of different types of companies. For instance, section 114(2) requires the independent expert, among other matters:

(a) (i) to be qualified, competent and experienced to:

(aa) understand the type of arrangement proposed;

(bb) evaluate the consequences of the arrangement; and

(cc) assess the effect of the arrangement on the value of securities and on the rights and interests of a holder of any securities, or a creditor of the company; and

(ii) able to express opinions, exercise judgment and make decisions impartially.

(b) Not-

(i) have any other relationship with the company or with a proponent of the arrangement, such as would lead a reasonable and informed third party to conclude that the integrity, impartiality or objectivity of that person is compromised by that relationship;

(ii) have had any relationship contemplated in subparagraph (i) within the immediately preceding two years; or

49 Section 164(11) of the Act.

50 As pointed out by Latsky, there could be an overlap between the independent expert reports required for fundamental transactions and those required for affected transactions. See Latsky 2014 Stell LR 369.

51 See Pick 'n Pay Stores 2016 https://www.picknpayinvestor.co.za/downloads/investorcentre/circulars/2016/stores-limited-24-june-2016.pdf. Annexure 1 of the circular contains a report from the Independent Expert. In the report, the independent expert makes it clear that it was prepared at the request of the directors.

Directors are required to undertake valuations of companies during affected transactions taking into consideration that $\mathrm{s} 218$ (2) of the Act provides that any person who contravenes any section of the Act may be liable to any person for the loss or damage suffered by such a person due to the contravention. 
(iii) be related to a person who has or has had a relationship contemplated in subparagraph (i) or (ii).

In addition, section 114(3) provides that the expert retained by the board to prepare a report to the board in respect of an arrangement must, at a minimum, prepare a report that:

(a) all prescribed information relevant to the value of the securities affected by the proposed arrangement;

(b) identify every type and class of holders of the company's securities affected by the proposed arrangement;

(c) describe the material effects that the proposed arrangement will have on the rights and interests of the persons mentioned in paragraph (b);

(d) evaluate any material adverse effects of the proposed arrangement against-

(i) the compensation that any of those persons will receive in terms of that arrangement; and

(ii) any reasonably probable beneficial and significant effect of that arrangement on the business and prospects of the company;

(e) state any material interest of any director of the company or trustee for security holders;

(f) state the effect of the proposed arrangement on the interest and person contemplated in paragraph (e); and

(g) include a copy of sections 115 and $164 . .^{54}$

Regulation 90 is also important concerning the valuation of shares, despite its imperfections, as it sets out important details about the valuation of the relevant shares in case of takeovers. ${ }^{55}$ Based on the process and the disclosures required by the regulation, it suggested that shareholders may form an opinion as to the fair value of their shares even before appointing their own experts. The regulation provides as follows, in part:

(4) An independent expert's valuation of the offeree regulated company [the company's shares] must be performed in accordance with generally accepted valuation approaches and methods in use in the market from time to time including-

54 Section 114(3) of the Act.

$55 \quad$ Defined as "Affected Transactions" under s 117(1)(c) of the Act. 
(a) capitalisation, income or cash flow approach which relies on the 'value-in-use' principle and requires determination of the present value of future cash flows over the useful life of the asset or business;

(b) comparative or market approach that relies on the principle of 'willing buyer, willing seller' and requires that the amount obtainable from the sale of an asset or undertaking is determined as if in an arm's-length transaction;

(c) cost approach that relies on historical amounts spent on the asset or undertaking.

(5) In respect of mineral companies, the valuation approach and methodology must comply with the SAMVAL code.

(6) The content of the independent expert's fair and reasonable opinion in relation to an offer must, among other things, include-

(a) the date of the fair and reasonable opinion, and confirmation that the fair and reasonable opinion has been given to the relevant board concerned for the sole purpose of assisting the relevant board in forming and expressing an opinion for the benefit of holders of relevant securities, excluding the offeror;

(b) a statement that the fair and reasonable opinion may be included, in whole or in part, in any required regulatory announcement or documentation;

(c) a clear expression of opinion dealing with the fairness and reasonableness of the offer consideration(s) in regard to holders of relevant securities, excluding the offeror;

(d) a detailed list of all source documentation used and reviewed and work done in accordance with the scope of the appointment;

(e) a statement of the valuation approach adopted, the methods employed and all material assumptions underlying the valuation approach and methodology;

(f) a range of final valuation values attributable to the relevant securities or assets and a most likely value used as the core number for purposes of the expression of the opinion;

(g) any other valuation or pricing approaches and methodologies used in corroborating the expression of the opinion e.g. the comparative approach or cost approach;

(h) the fee payable or paid to the independent expert for the fair and reasonable opinion and confirmation that the fee is not contingent on or related to the outcome of the offer; and 
(i) a declaration of the independence and competence of the independent expert, which may require evidential justification if the Panel is not satisfied with the declaration. ${ }^{56}$

The valuation methodologies prescribed in regulation 90(4) are well-known in practice. ${ }^{57}$ Section 164(16) provides that the fair value must be determined as at the date on which and the time immediately before the company adopted the resolution that gave rise to the appraisal rights. This is relevant to the valuation to ensure that shareholders do not unduly benefit or lose value on their shares because of the implementation of the transaction. The approach is in line with our case law concerning the valuation of shares during takeovers. ${ }^{58}$ Accordingly, the starting point should be before the trigger date of the transaction because only the potentialities or disadvantages that existed before the transaction should be considered. ${ }^{59}$

As indicated above, the courts under section 164(15)(c)(ii) must determine the fair value of the shares, and the court may in its discretion appoint one or more appraisers to assist it in determining fair value in terms of section 164(15)(c)(iii). The role of the independent expert becomes crucial where there is a dispute as to fair value, and the courts may be persuaded by such experts when called to establish fair value during appraisal rights proceedings. Where relevant, the courts may also consider foreign case law, particularly the courts' decisions where the appraisal right is well-established, such as in Delaware State, where the remedy has been available for some time. It has been suggested that the decisions of the Delaware courts may provide some guidance because they have "grappled with the thorny issue for years". 60 It is common practice in terms of the Act for the directors to rely on such valuations issued by independent experts. ${ }^{61}$ Any further guidance in the Act or regulations on how valuation must be undertaken is inappropriate and may lead independent experts not to approach valuations in a rigorous manner and to adopt a tick box mentality.

$56 \quad$ Regulation 90(4)-90(6) of the Regulations.

57 See Seligson 2016 BTCLQ 10. The methods listed in the article include those prescribed by the Regulations.

58 See Seligson 2016 BTCLQ 9.

59 See Seligson 2016 BTCLQ 10.

60 Davids, Norwitz and Yuill 2010 Acta Juridica 360.

61 Pioneer Food Group 2019 https://pioneerfoods.co.za/2019/08/29/2430/ para 24.2 provides: "The Independent Board, after due consideration of the report of the Independent Expert, has determined that it will place reliance on the valuation performed by the Independent Expert for the purposes of reaching its own opinion regarding the PepsiCo Offer and the Per Share Scheme Consideration...". 


\section{Limiting the effect of the exercise of appraisal rights}

Companies are wary of the appraisal right. Some view it as an impediment to engaging in fundamental transactions. ${ }^{62}$ For this reason, companies and their advisers routinely ensure that transaction agreements incorporate conditions to deal with the appraisal right. ${ }^{63}$ In some cases, the agreements are aimed at ensuring that shareholders can exercise the appraisal right in respect of only a limited percentage of the shares they hold, commonly, $5 \%$, in aggregate..$^{64}$

In addition, companies attempt to limit the amount of money they may be required to pay if the appraisal right is exercised. This is done by stating a specified percentage beyond which the company would not pay. ${ }^{65}$ The conditions allow the company to terminate the transaction should it be faced with paying a high consideration for the shares due to many shareholders exercising and making demands in terms of their appraisal rights. At the same time, the condition precedent ensures that the company can control the implementation of the transaction without risking being forced to proceed with implementation once the transaction has been approved by the requisite majority of shareholders. Though accepted in practice, ${ }^{66}$ these terms and conditions have been questioned by some researchers. ${ }^{67}$ It is asserted that such conditions "neutralise(...) the threat of uncertainty created by section 164 in relation to potential cash demands made by the shareholders in a offeree company". ${ }^{68}$ Further, it has been asserted that such terms and

62 See Cassim "Shareholder Remedies and Minority Protection" 798.

63 A typical condition precedent may be two-pronged and read as follows: "Where shareholders exercise their Appraisal Rights, either: - Shareholders give notice objecting to the Resolution as contemplated in section 164(3) of the Act and vote against the Resolution at the General Meeting, in respect of no more than, in aggregate, $5 \%$ (five percent) of all the Shares; or - If Shareholders do give notice objecting to the Resolution at the General Meeting, in respect of more than, in aggregate, $5 \%$ (five percent) of all the Shares and vote against the Resolution, Shareholders have not exercised Appraisal Rights, by giving valid demands in terms of sections 164(5) to 164(8) of the Companies Act, in respect of more than, in the aggregate, 5\% (five percent) of all the Shares." Similar wording was used in a Circular issued by Sovereign Investment Foods Limited dated 11 December 2015. (See Juspoint Nominees (Pty) Ltd v Sovereign Food Investments Limited (BNS Nominees (Pty) Ltd Intervening) 2016 ZAECPEHC 15 (26 April 2016) (hereafter the Sovereign case).

64 See Sovereign.

65 See fn 63 above for a typical condition.

66 See Yeats 2014 Stell LR 338.

67 See Yeats Effective and Proper Exercise of Appraisal Rights 209.

Yeats Effective and Proper Exercise of Appraisal Rights 209. 
conditions may be challenged under section 6 of the Companies Act $2008 .{ }^{69}$ The debates on this issue are beyond the scope of this article.

\section{Case law}

One of the first cases ${ }^{70}$ decided about the appraisal right was the matter of Juspoint Nominees (Pty) Ltd (Juspoint) $v$ Sovereign Food Investments Limited, (BNS Nominees (Pty) Ltd Intervening). ${ }^{71}$ Briefly, the facts are that Sovereign Food Investments Ltd (Sovereign) proposed a share repurchase in terms of section 48(8). The proposal was to be implemented as a scheme of arrangement as contemplated in terms of section 114 of the Act read with the Takeover Regulations (the transaction). One of the conditions precedent to the transaction was that:

With regard to Shareholders exercising their Appraisal Rights, either:

- $\quad$ Shareholders give notice objecting to the Repurchase Resolution and /or the Notional Funding Repurchase Resolution as contemplated in section 164(3) of the Companies Act and vote against the Repurchase Resolution and / or the Notional Funding Repurchase Resolution at the General Meeting, in respect of no more than, in aggregate, 5\% (five percent) of all the Shares; or

- If Shareholders do give notice objecting to the Repurchase Resolution and / or the Notional Funding Repurchase Resolution at the General Meeting, in respect of more than, in aggregate, $5 \%$ (five percent) of all the Shares, then within 25 (twenty five) Business Days following the date on which the Company has sent notice to such Shareholders in accordance with section 164(4) of the Companies Act, Shareholders have not exercised Appraisal Rights, by giving valid demands in terms of sections 164(5) to 164(8) of the Companies Act, in respect of more than, in the aggregate, $5 \%$ (five percent) of all the Shares.

Should all of the conditions precedent referred to above not be fulfilled or waived by Sovereign (where possible), as the case may be, then the Share Acquisition (and the Scheme) will not become operative and shall be of no force or effect, ${ }^{72}$

Juspoint, one of the minority shareholders in Sovereign, was aggrieved by the proposed share repurchase and made it clear that it intended to vote against the resolutions and exercise its rights in terms of section 164 . Subsequently, the meeting to pass the proposed resolutions was held, and

69 Section 6 deals with anti-avoidance. In terms of the section, a court and, in the case of a listed company, an exchange, have the power to declare the particular condition or the entire offer agreement void.

70 See Mashabane 2016 De Rebus.

71 See Sovereign.

72 Sovereign para 18. 
the dissentients voted against the resolutions. The dissentients then proceeded to demand payment of the fair value of their shares. The dissentients owned more than the percentage stated in the condition precedent. This presented a problem to Sovereign as the transaction could not be implemented. Sovereign devised an alternative transaction. It was designed not to trigger appraisal rights in terms of section $164 .{ }^{73}$

In February 2016, Sovereign released another circular, its purposes including to revoke the special resolutions as well as the ordinary resolutions passed at the January 2016 general meeting that were included in the December 2015 circular, and instead to approve the revised transactions relating to the failed repurchase transaction, to approve a Black Economic Empowerment (BEE) transaction and to approve an executive management remuneration policy. ${ }^{74}$

The proposed transaction raised new issues for both the company and the dissentients relating to the interpretation of section 164. Of particular importance is the effect of the exercise and the making of a demand under the appraisal right remedy on the voting rights of the dissentients. ${ }^{75}$ For instance, what were the rights in the proposed new transaction of those shareholders who had voted against the earlier transaction? They had not been paid a fair value for their shares at that stage. Should their rights continue to be suspended in line with section 164(9)? What were their rights when the company proposed a new resolution to revoke the resolution that gave rise to the exercise of the appraisal right as contemplated by section 164(9)(c)?

In terms of the decision of the court in the Sovereign decision, one of the offending paragraphs in the February 2016 circular reads as follows:

VOTING AND ATTENDANCE AT THE NEW GENERAL MEETING

If you are a Dissenting Shareholder whose rights have not been reinstated in terms of section 164(10) of the Companies Act, you will not be entitled to attend and vote at the New General Meeting. However, if you withdraw your demand made in terms of section 164(5) to 164(8) of the Companies Act, then your rights in terms of the Shares held by you will be reinstated in terms of section 164(10) as read with section 164(9)(a) of the Companies Act and you will be entitled to attend and vote at the New General Meeting. ${ }^{76}$

Sovereign para 27.

Sovereign para 41.

Section 164(9) of the Act.

Sovereign para 38. 
The court held that the far-reaching curtailment of shareholders' rights contemplated under section 164(9) was premised on such shareholders; the only interest being to receive payment of fair value for its shares. ${ }^{77}$ However, once it was clear that such payment would not be forthcoming because the proposed scheme was not operative or effective, "the fons et origo of the appraisal rights cease[d] to exist and the rights of the shareholder which had been sterilised, [were] reinstated". ${ }^{78}$ The court agreed with the argument of Juspoint that the non-fulfilment of the appraisal right condition precedent had the effect that the earlier scheme, as well as the appraisal right under it had no legal effect at all, and were rendered void ab initio. ${ }^{79}$

The court then dealt with the disclosures in the circular, and held as follows:

I am also satisfied that Sovereign's proposed resolutions for the 29 March
meeting are not expressed with sufficient clarity and specificity and are not
accompanied by sufficient information or explanatory material to enable a
shareholder who is entitled to vote on the resolution to determine whether to
participate in any meeting called to seek to influence the outcome of the vote
on the resolutions. ${ }^{80}$

While the main thrust of the decision in the Sovereign case was the appraisal right under section 164, the court also touched on the rights of shareholders in terms of section 163 of the Act. The court stated that the jurisprudence developed under section 252 of the Companies Act of 1973 was relevant to determine what oppressive or unfairly prejudicial conduct is in terms of the Act. ${ }^{81}$ The court held that such conduct is not limited to strict violation of a shareholder's legal right. A disregard of a shareholder's interest would also qualify for protection. ${ }^{82}$ The court ruled that Sovereign's conduct and its proposed course of conduct were prejudicial and oppressive to the rights of dissenting and minority shareholders and disregarded their interests, ${ }^{83}$ and further that this was unfair, as it locked in the dissentients and prevented them from fairly participating in its business. ${ }^{84}$ The court also rejected the argument that the dissentients could just withdraw their appraisal rights, as this sought to dictate what shareholders are entitled to and was unfair. ${ }^{85}$ More importantly, the court stated, the effect of this argument would be that the

Sovereign para 77.

Sovereign para 77.

Sovereign para 32.

Sovereign para 77.

Sovereign para 56.

Sovereign paras $57,58$.

Sovereign para 63.

Sovereign para 63.

Sovereign para 64. 
dissentients would lose their appraisal rights. ${ }^{86}$ Further, another unfairness could result in that Sovereign could proceed with its initial scheme (against which the dissenting shareholders voted), but without the consequences of having to allow the dissenting shareholders to follow their appraisal rights, because a sufficient number of dissentients had withdrawn their appraisal rights in the initial scheme, and could simply withdraw the latest proposal. ${ }^{87}$ Accordingly, the court concluded that this would be unjust, unfair and unreasonable. ${ }^{88}$ Finally, the court ruled as follows:

- $\quad$ that the condition precedent referred to under paragraph 4.8 of the December 2015, circular has neither been fulfilled nor has it been waived, and that the share acquisition (and the scheme) have not become operative; 89

- $\quad$ prohibiting the minority shareholders from participation in the resolution to revoke the previous resolution (where the minorities participated, even if the proposed resolution is likely to be adopted), falls foul of the requisites of section 163, and constitutes oppressive and/or unfairly prejudicial conduct which disregards the interests of the dissenting shareholders; 90

- $\quad$ Sovereign's proposed resolutions contained in the February 2016 circular to shareholders are not expressed with sufficient clarity and specificity and are not accompanied by sufficient information or explanatory material to enable a shareholder who is entitled to vote on the resolution to determine whether to participate in the meeting called to seek to influence the outcome of the vote on the resolutions as required by section $65(4)$ of the Act; 91 and

- Sovereign's conduct towards the dissentients is not only oppressive and unfairly prejudicial to the dissentients but in particular, that it unfairly disregards the interests of the applicants, the intervening parties and minority shareholders in general. ${ }^{92}$

Sovereign para 64.

Sovereign para 64.

Sovereign paras $64,65$.

Sovereign para 85.

Sovereign para 87.

Sovereign para 89.

Sovereign para 88. 
Another matter where the court grappled with the appraisal right remedy is the Loest case..$^{93}$ In the matter, the court dealt with an application by a dissenting shareholder who wished to rely on his status as a shareholder to request company information to determine the fair value of its shares using the Promotion of Access to Information Act (PAIA). Interestingly, the shareholder was not applying to the court for the determination of fair value as contemplated in section 164(14) but instead sought to obtain specific information from the company so that his auditor would perform the valuation of the shares. The shareholder argued that the information was necessary to exercise appraisal rights under section 164. The respondents opposed the application on the main ground that the applicant did not require the information for the protection of its rights and that the appraisal rights procedure provided by section 164 represented an alternative remedy to access information in terms of PAIA.

Briefly, Loest was a shareholder in the respondent's private companies when the section 164 appraisal right was triggered. The trigger was the conversion of the respondent's ordinary share capital from shares of par value to shares of no-par value and the amendment of the memoranda of incorporation of the respondent. In asserting the right under section 164, the applicant asked the assistance of BDO Corporate Finance, who established that in their view, the shares were valued at a different value than that offered to the applicant. The applicant subsequently sought access to specified information from the respondent, relying on the provisions of PAIA. The applicant averred that the information sought was necessary to determine the fair value of the shares as contemplated in terms of section $164 .{ }^{94}$

The respondents challenged the applicant's status and argued that he had no standing as he was not a shareholder, having lost that status in terms of section 164(9). ${ }^{95}$ The applicant argued that the section was being incorrectly applied, and the court agreed with his version. The court indicated that the applicant was still a shareholder to receive fair value for his shares. The court

\footnotetext{
$93 \quad$ See Loest 73.

94 See Loest para 11.

95 Section 164(9) of the Act provides that: "A shareholder who has sent a demand in terms of subsections (5) to (8) has no further rights in respect of those shares, other than to be paid their fair value, unless - (a) the shareholder withdraws that demand before the company makes an offer under subsection (11), or allows an offer made by the company to lapse, as contemplated in subsection (12)(b); (b) the company fails to make an offer in accordance with subsection (11) and the shareholder withdraws the demand; or (c) the company, by a subsequent special resolution, revokes the adopted resolution that gave rise to the shareholder's rights under this section."
} 
disagreed with the respondent's argument and held that section 164 does not deprive the applicant of his status as a shareholder. The section merely removes other trappings or privileges while a dissenting shareholder pursues the appraisal right remedy. ${ }^{96}$

The court held that the applicant was not precluded from using PAIA to obtain the relevant information to be able to exercise its appraisal right in terms of section 164 of the Act, but that it was inappropriate because section 164 has its own built-in mechanisms to protect a shareholder's right to receive the fair value of its shares. ${ }^{97}$

The applicant in the case did not apply to the court for a determination of the fair value of his shares as contemplated in terms of section 164(14). It is suggested that rather than relying on PAIA to obtain information to determine the fair value of the shares, the applicant could have applied to the court in terms of section 164(14). The application would then have triggered the mechanism allowing the court to exercise its discretion and appoint appraisers in terms of section 164(15)(c)(iii)(aa). ${ }^{98}$

Another matter dealing with the appraisal right remedy is that of Cilliers $v \mathrm{La}$ Concorde Holdings Limited, ${ }^{99}$ (Mr Cilliers, the applicant in this matter, is one of the intervening parties in the Sovereign Food Investments Ltd case discussed above). In this case, the court had to determine whether the shareholders of a holding company are entitled to exercise their appraisal rights in terms of section 164 of the Act, where a wholly owned subsidiary of the holding company proposes to dispose of all or the greater part of its assets, as contemplated in terms of section 112, read with section 115(2)(b). By agreement between the parties, an application was made to the court for a determination of a question of law in terms of Rule 6(5)(d)(iii) of the Rules of Court, ${ }^{100}$ initio litis.

The brief facts are that Cilliers was a minority shareholder in La Concorde Holdings Ltd (the holding company). In turn, the holding company held $100 \%$ of the issued shares in KWV SA (Pty) Ltd (KWV SA). In May 2016, KWV SA announced on the Stock Exchange News Service, commonly known as

\footnotetext{
$96 \quad$ Loest para 13.

97 See Loest paras 25, 40.

98 Also see discussions in Cilliers $v$ La Concorde Holdings Limited 2018 ZAWCHC 68 (14 June 2018) discussed below in the next paragraph. Cilliers v La Concorde Holdings Limited 2018 ZAWCHC 68 (14 June 2018) (hereafter the Cilliers case).

100 Rule 6(5)(d)(iii) in GN R48 in GG 999 of 12 January 1965 as amended, commonly known as the Uniform Rules of Court.
} 
SENS, that it proposed to dispose of all its operational assets to another company. A few weeks later, in line with the announcement, the holding company notified its shareholders about a proposed general meeting. At the meeting, the company proposed to put to the vote several resolutions in accordance with section 112 read with section 115(2)(b) of the Act. Subsequently, Cilliers and other shareholders (dissentients) of the holding company notified the company and complied with other requirements of section 164 of the Act and thereby became entitled to exercise their appraisal rights. In turn, the holding company proceeded to make an offer to the dissentients in line with the relevant requirements of section 164. The dissentients believed that the offer made was inadequate as contemplated in section 164(14)(b), and accordingly rejected it. The dissentients approached the court to appoint two appraisers ${ }^{101}$ to determine a fair value of their shares as contemplated in terms of section 164(14). The holding company and the other respondents argued that dissentients were entitled to their appraisal rights only where the holding company, rather than KWV SA, the subsidiary, adopted a resolution contemplated in section 112 of the Act.

This argument would have the effect that minority shareholders would have no appraisal rights whatsoever, even if their holding company undertook a fundamental transaction, even though such a transaction might result in a significant change in a company substructure, which could negatively affect the company's shareholders. Notably, the respondents at the initial stages of the proposed transaction had accepted that the applicants were entitled to exercise their appraisal rights and had included the requisite notices in compliance with section 164 , but that the respondents had later changed their stance. ${ }^{102}$

Section 115(8) of the Act was necessary for the applicant's argument. In this regard, the section provides:

The holder of any voting rights in a company is entitled to seek relief in terms of section 164 if that person-
(a) notified the company in advance of the intention to oppose a special resolution contemplated in this section; and
(b) was present at the meeting and voted against that special resolution. ${ }^{103}$

\footnotetext{
101 See s 164(15)(c)(iii)(aa) of the Act.

102 See Cilliers para 10.

103 Section 115(8) of the Act.
} 
The court held that the clear wording of section 115(8) granted the applicants' appraisal rights as shareholders in the holding company when a subsidiary of the holding company disposes of all or the greater part of its assets or undertaking where section 115(2)(b) is applicable. Section 115(8) of the Act extends the category of shareholders entitled to exercise section 164 appraisal rights. ${ }^{104}$ This may include other shareholders who have voting rights, even though section 164 did not contemplate this. Based on the available literature, it appears that this is the first case where a court exercised its discretion to appoint appraisers to establish a fair value of the relevant shares. ${ }^{105}$ The important principle set by the court is that minority shareholders are entitled to appraisal rights under section 164, where a holding company undertakes a fundamental transaction.

In a recent case of Standard Bank Nominees (RF) Proprietary Limited (applicants) v Hospitality Property Fund Limited (Hospitality), ${ }^{106}$ the court dealt with the effect of giving notice by a shareholder to object to a proposed resolution, ${ }^{107}$ and the demand by a shareholder to be paid fair value, ${ }^{108}$ on the existing rights of a shareholder as contemplated by section 164(10). The court also discussed section 164(14), dealing with an application by a shareholder to court for its determination of the fair value of the relevant shares. In this matter Standard Bank Nominees (RF) Proprietary Limited (Nominees) was a registered holder of $B$ linked units. At the same time, The Standard Bank Limited of SA was the beneficial owner (as the trustee for an investment fund (the Fund)) of the linked units in Hospitality. The Fund appointed a Manager in terms of the Collective Investment Control Act of 2002, and the Manager, in turn, appointed an Advisor. Purporting to act in terms of section 164 the Advisor gave notice to Hospitality, attended and voted against the scheme at the meeting of unitholders to activate the appraisal right remedy. Having followed the steps required in terms of section 164(5) to (8), and having applied to court for a determination of fair value, the Advisor was advised that it had no legal standing to apply to court to determine the fair value of the shares in terms of section 164(14), due to various errors. The application was withdrawn.

The applicants' view was that due to several errors committed during the appraisal right proceedings, including that the party which acted in terms of section 164 had no legal standing, the attempted exercise of the appraisal

\footnotetext{
104 Cilliers para 49.

105 See s 164(14)(c)(iii)(aa).

106 Standard Bank Nominees.

107 Section 164(3) of the Act.

108 Section 164(5) of the Act.
} 
right under section 164 was invalid from the beginning. Therefore, all the steps taken to exercise the appraisal right, including the application to court, had no legal effect on the rights of the Nominees in and to the shares, because the Nominees had not undertaken any of the compulsory steps to perfect their appraisal right as required by section $164 .{ }^{109}$

Accordingly, the applicants averred that none of the consequences that flow from a valid exercise of the appraisal right in terms of section 164 could follow and, as such, the rights of the Nominees (the registered shareholder) to the shares substituted under the implemented scheme of arrangement remained valid, enforceable and actionable. ${ }^{110}$ During the appraisal right proceedings, Hospitality declared and paid dividends to shareholders, excluding the Nominees. The argument went further - that as the Nominees retained their rights, the applicants contended that the Nominees were entitled to the payment of all dividends declared and paid by Hospitality during the appraisal proceedings. As an alternative, should the court have rejected the earlier contention, the applicants argued that the Nominees would be entitled to be paid the fair value of its shares, and this could also be achieved under section 163. ${ }^{111}$

Hospitality, on the other hand, argued that in terms of the appraisal right procedure, a dissentient's rights are fixed from the moment it lodges a demand to be paid fair value in terms of section 164(5) to (8). According to Hospitality, once that has been done, the dissentient has no further rights regarding its shares, except for the right to be paid fair value for the shares. Therefore, as the argument continued, the Nominees' withdrawal of the application to the court to determine fair value could not affect its rights in respect of the shares because it lost its rights when it demanded to be paid fair value. ${ }^{112}$ Hospitality further argued that even if the court reinstated the Nominees' rights in respect of the shares, it was not entitled to the payment of the dividends distributed to shareholders in the interim because it had

\footnotetext{
109 Standard Bank Nominees para 30.

110 Standard Bank Nominees para 30.

111 Section 163 of the Act deals with oppressive or prejudicial conduct or from abuse of separate juristic personality of a company. In terms of the section, a shareholder or a director of a company may apply to a court for appropriate relief, including that the company unfairly prejudiced or unfairly disregarded the interests of, the applicant. The court may then make an order including an order directing an issue or exchange of shares, an order directing the company or any other person to restore to a shareholder any part of the consideration that the shareholder paid for shares, or pay the equivalent value, with or without conditions, or an order to pay compensation to an aggrieved person, subject to any other law entitling that person to compensation. 
waived its right to the dividends. ${ }^{113}$ Briefly, the court focussed on two enquiries, being the following:

- $\quad$ the application section 164(14), dealing with an application to court by a dissentient to determine the fair value of its shares, on the right of a dissentient as a shareholder as contemplated in section 164(10) read with section 164(9), ${ }^{114}$ and a claim by the Nominees to be paid the dividends declared and distributed by Hospitality from the time that the units were replaced in terms of the scheme of arrangement; ${ }^{115}$ and

- the legality of the steps taken during the appraisal proceedings, particularly by the Advisor. ${ }^{116}$

The court analysed the applicable provisions and rejected Hospitality's various arguments. The court held that when the directors' offer under section 164(11) expired after 30 business day, and the dissentient had not accepted it, the offer lapsed, regardless of whether the dissentient rejected the offer or not. ${ }^{117}$ Further, the court found that the Nominees, as the registered shareholder, failed to institute an application to court for the determination of fair value within 30 business days of the offer being made. Consequently, its rights regarding its shares were without interruption as if the appraisal right had never been exercised. The court indicated that there is a clear structural and contextual link between sections 164(12)(b) and 164(9)(a), 164(10) and 164(14)(b). ${ }^{118}$ Section 164(10), on its plain terms, does not remove any rights held by a dissentient but simply aims to prescribe what the default position is in the event that a dissentient does not accept an offer for fair value and fails to institute an application to court within the requirements of section 164(14). ${ }^{119}$ When a dissentient applies to court under section 164(14), it makes a choice to exit for fair value to be determined by the court, and is bound by the election at this point and not when it makes a demand under sections $164(5)$ to $(8) .^{120}$

The court held that what is critical to the enforcement of the appraisal right is that where a shareholder does not want to accept the offer of fair value made by the company, it had to apply to the court for a determination of fair value

\footnotetext{
$113 \quad$ Standard Bank Nominees para 72.

114 Standard Bank Nominees para 3.

115 Standard Bank Nominees para 4.

116 Standard Bank Nominees para 5.

117 Standard Bank Nominees para 61.

118 See Standard Bank Nominees para 62.

119 See Standard Bank Nominees para 68.

120 See Standard Bank Nominees para 69.
} 
before the end of the 30-day period prescribed in section 164(14)(b), read with section 164(12)(b). If it fails to do so, it loses its right to approach the court to determine fair value. This would initiate the reinstatement of a shareholders' full right in terms of section 164(10). ${ }^{121}$ This being the case in respect of the Nominees, their rights were accordingly reinstated. ${ }^{122}$ The court also rejected the contention of Hospitality that the Nominees waived their rights for the payment of the dividend. The court held that a waiver of rights could be done by a party only with full knowledge of the legal consequences of such a waiver. ${ }^{123}$ This could not be the case in the present case, because all parties were mistaken as to the validity of the underlying enforcement steps of the Nominees' appraisal right. Therefore, the Nominees cannot be said to have had the requisite knowledge of the legal consequences of the waiver of its rights in its shares. ${ }^{124}$ It could not be said that had the Nominees known that the steps taken under section 164 were invalid, and that it had lost its right to seek a declaration of fair value from the court it would nonetheless have expressly agreed to waive its entitlement to be paid the dividend. ${ }^{125}$

The complex relations between the parties seems to have contributed to the failure of the appraisal rights proceedings in this matter. ${ }^{126}$ This resulted in a person who had no legal standing purporting to exercise section 164 appraisal rights instead of the Nominees, the registered shareholder. This is a warning to parties involved in fundamental transactions to ensure that all procedural requirements are met during appraisal rights proceedings.

Even though the court did not have to consider the determination of fair value, the judgment brought clarity and certainty on the effect of the lapsing of an offer made in terms of section $164(11)^{127}$ and the reinstatement of the

\footnotetext{
121 See Standard Bank Nominees para 70.

122 See Standard Bank Nominees para 70.

123 See Standard Bank Nominees para 77.

124 Standard Bank Nominees para 78.

125 See Standard Bank Nominees paras 75-79.

126 See Standard Bank Nominees para 6.
}

127 Section 164(11) of the Act provides that: "Within five business days after the later of(a) the day on which the action approved by the resolution is effective; (b) the last day for the receipt of demands in terms of subsection (7) (a); or (c) the day the company received a demand as contemplated in subsection (7) (b), if applicable, the company must send to each shareholder who has sent such a demand a written offer to pay an amount considered by the company's directors to be the fair value of the relevant shares, subject to subsection (16), accompanied by a statement showing how that value was determined." 
dissenting shareholder's rights in terms of section $164(10) .^{128}$ The issue of the determination of fair value by the courts will no doubt arise in future appraisal right proceedings. After the judgment reinstating the Nominees as a shareholder of Hospitality and ordering Hospitality to pay the dividends claimed, the company paid in compliance with the court order. ${ }^{129}$

\section{Evaluation and concluding remarks}

The legislature has added the appraisal right remedy to the arsenal of minority shareholders' rights when companies undertake fundamental transactions. Despite its detailed and complex process, the developing case law should clarify its application. This should be welcomed, and the remedy should further strengthen minority shareholder protection and encourage shareholder activism when companies undertake a fundamental transaction. It is a significant enhancement of shareholder protection, despite the claims of some of its detractors. ${ }^{130}$ Initial concerns that a threat of exercising the appraisal right may stifle fundamental transactions have not been proven. ${ }^{131}$ The scheme of arrangement, which has the potential to attract the appraisal right remedy, is still a favourable method of undertaking a takeover by companies. ${ }^{132}$ General offers ${ }^{133}$ as a method of achieving takeovers have not significantly increased, despite offering an advantage in that the appraisal right remedy is not triggered when a general offer is made to shareholders. ${ }^{134}$

128 Section $164(10)$ of the Act provides that: "If any of the events contemplated in subsection (9) occur, all of the shareholder's rights in respect of the shares are reinstated without interruption."

129 See Hospitality Property Fund 2019 https://www.sharenet.co.za/v3/sens_ display .php?tdate $=20191121080000 \&$ seq $=8 \&$ scode $=/$.

130 See Yeats 2014 Stell LR 341.

131 See Yeats Effective and Proper Exercise of Appraisal Rights 167, where the concerns were raised.

132 See TRP Annual Reports for the 5 years between 31 March 2014 to 31 March 2018 (TRP 2020 https://trpanel.co.za/financials/). The reports consistently show a higher number of fundamental transactions in the form of schemes of arrangement even though such transactions attract appraisal rights. It is suggested that the ease and certainty of a scheme of arrangement as a method of achieving a takeover surpass those of other methods.

133 A general takeover offer is one of the techniques to acquire control of a company and refers to an offer to acquire the required shares or all the shares in the target company. See Cilliers et al Corporate Law paras 26.30-26.31. Provided that the requisite percentage is achieved during the offer period, a general offer may then be followed by a squeeze out procedure in terms of $\mathrm{s} 124$ of the Act, thus ensuring that the acquirer holds 100 per cent of the target company shares.

134 See TRP Annual Reports for the 5 years between 31 March 2014 and 31 March 2018 (TRP 2020 https://trpanel.co.za/financials/). 
It is suggested that the discretion of the court in making "an appropriate order of costs, having regard to any offer made by the company, and the final determination of the fair value by the court"135 is aimed at encouraging the settlement of litigation by the acceptance of reasonable offers. ${ }^{136}$ The cost order is a risk to dissentients who blindly insist on getting what they consider a "fair value" without considering the fair value established by the independent expert. It is notable that companies and their advisers inform dissentients of this risk in practice. ${ }^{137}$ This advice is often combined with reference to the fact that an independent expert has determined a fair value of the relevant shares. ${ }^{138}$ In addition, shareholders are reminded that should the percentage set as a condition precedent be exceeded, and the transaction may not proceed. ${ }^{139}$ This practice may be a double-edged sword. At first sight, this may seem good practice, but it is also arguable that such advice may be intended to discourage shareholders from exercising their appraisal rights due to concerns that the proposed transaction may fail. On the other hand, it is also arguable that the warning about the costs may have the effect of discouraging shareholders from applying to a court to determine the fair value of their shares for fear of a cost award against them.

It is arguable whether the appraisal right remedy affects the equality of treatment of shareholders ${ }^{140}$ during affected transactions. The exercise of the

135 Section 164(15)(c)(iv) of the Act.

136 See rule 34 in GN R48 in GG 999 of 12 January 1965 as amended. Under the rule the court may refuse to award costs to a successful party which refused to settle a matter even if that party is successful in the main action. This may be the case where the final award by the court to a plaintiff is less than the offer made by the opposing party, and the plaintiff refused to accept the offer without proper grounds for the refusal.

137 See Pick 'n Pay Stores 2016 https://www.picknpayinvestor.co.za/downloads/investorcentre/circulars/2016/stores-limited-24-june-2016.pdf para 8.1.6 where it is stated: "Before exercising their rights under section 164 of the Companies Act, Holdings Shareholders should have regard to the fact that the court is empowered to grant a costs order in favour of, or against, a Dissenting Shareholder, as may be applicable."

138 Trans Hex Group 2019 https://www.transhex.co.za/wp-content/uploads/2019/09/ TRANS-HEX-Shareholder-CIRCULAR.pdf. Para 12.6 of the circular states as follows: "Before exercising their rights under section 164 of the Companies Act, Shareholders should have regard to the following: having considered the terms and conditions of the Scheme, the Independent Expert has concluded that the terms and conditions of the Scheme are fair and reasonable to the Scheme Participants. Shareholders are referred to Annexure 1, which sets out the full text of the Independent Expert's report on the Scheme; and the Court is empowered to grant a costs order in favour of, or against, a Dissenting Shareholder."

139 See Pick 'n Pay Stores 2016 https://www.picknpayinvestor.co.za/downloads/investorcentre/circulars/2016/stores-limited-24-june-2016.pdf para 8.1.7, advising shareholders about the conditions for implementation of the transaction.

140 See s 119 of the Act which provides that: "(2) Subject to subsection (6), [subsection 6 deals with the discretion to exempt compliance], the Panel [TRP] must regulate any affected transaction or offer, and the conduct of the parties in respect of any such transaction or offer, in a manner that promotes the objects set out in subsection (1) 
appraisal right implies that shareholders who exercised the right may receive a higher payment than other shareholders. At first sight, this appears to be against the general principles applicable in takeover laws requiring that shareholders receive equal treatment during such transactions. The requirement for equality of treatment in takeovers is well-known, as indicated by commentators: "As a general rule, all holders of a regulated offeree company, must be treated equally in an affected transaction...". ${ }^{141}$ Arguably, this is acceptable. All shareholders are extended equal treatment in that they can elect to exercise their appraisal rights. The dissentients who succeed in securing a higher payment for their shares following the appraisal right process are not treated unequally, contrary to section 119(2)(b). They should be compensated for taking the risk that the appraisal right proceedings may not turn out in their favour. It is also possible that at the end of appraisal right proceedings a court may determine that a lower offer than that offered by the company is a fair value offer for the relevant shares. In that scenario, parties that exercised their appraisal rights may receive a lower offer than other shareholders. This is also acceptable, as those who exercise their appraisal rights must be aware of the risk that a court may determine a lower offer than that offered by the company to be fair. In this instance, the dissentient should bear the loss.

Section 164(20) provides that, unless the section expressly so provides, or the TRP rules otherwise in a particular case, a payment by a company to a shareholder in terms of this section does not oblige any person to make a comparable offer to other shareholders under section 125(2). The section provides specific circumstances under which a comparable offer must be made. Arguably, none of those circumstances would become applicable when a company undertakes a fundamental transaction that triggers the appraisal right. For this reason, it is not clear on what basis a shareholder may demand that the TRP rule that a company make a comparable offer under section 125(2) because dissentients are paid a different price, having exercised their appraisal rights. It is suggested that such a ruling by the TRP might constitute an unequal treatment of shareholders. The debates about and the application of section 164(20) in relation to section 125(2) are beyond the scope of this article.

and, without limiting the generality of that subsection, ensures- (b) that all holders of- (i) any particular class of voting securities of an offeree regulated company are afforded equivalent treatment". 
Luiz ${ }^{142}$ makes an interesting observation on the interaction of section 164 and section 115(3), which deals with a court application to review a resolution. A question may be asked as to whether a shareholder who exercises the appraisal right is precluded from invoking section 115(3) to review the transaction approved or can invoke both 164 and 115(3). ${ }^{143}$ Luiz suggests that shareholders must first decide their intention before selecting from the remedies available in terms of section 164 and 115(3). A shareholder who seeks to remain invested in the company may then elect to enforce section $115(3)$, so that the transaction is not implemented (assuming that a shareholder succeeds in the court application). At the same time, a shareholder who wishes to exit the company may rely on the section 164 appraisal right to obtain fair value for the shares. ${ }^{144}$

Researchers have suggested that the existence of the appraisal right may encourage arbitrage by shareholders where an investor acquires shares in a company after a takeover or a fundamental transaction was announced to extract a higher price for itself using the appraisal right process. ${ }^{145} \mathrm{~A}$ shareholder would then have an opportunity to profit in cases where the fair value demanded for the shares exceeds the transaction value or the cost of acquiring the shares appraised. ${ }^{146}$ It is suggested that the motive to profit from such a higher fair value should not preclude a shareholder from an entitlement to exercise the appraisal right, provided that the shareholder meets all the requirements. ${ }^{147}$ It remains to be seen how arbitrageurs use the section to their benefit. Actions by arbitrageurs may also indirectly benefit other minority shareholders who may not have the means to launch appraisal rights proceedings. The risk of engaging in an appraisal right procedure may encourage companies to make fair valued offers at the beginning of the transaction to reduce the risk of shareholders' exercising their appraisal rights and consequent delays and related unforeseen legal costs. ${ }^{148}$ There is a link between the appraisal right and shareholder activism in the USA. The problems experienced elsewhere in connection with the appraisal right are likely to also feature in SA. ${ }^{149}$

\footnotetext{
142 Luiz 2014 SA Merc LJ 579.

143 See Luiz 2014 SA Merc LJ 579.

$144 \quad$ Luiz 2014 SA Merc LJ 579.

145 See Yeats Effective and Proper Exercise of Appraisal Rights 77.

146 See Yeats Effective and Proper Exercise of Appraisal Rights 77-80. See the discussions under those paragraphs as to how hedge funds and arbitrageurs benefit by using the appraisal right process.

147 See Yeats Effective and Proper Exercise of Appraisal Rights 207.

148 See Davids, Norwitz and Yuill 2010 Acta Juridica 360.

149 See Yeats 2014 Stell LR 341.
} 
As already stated, section 164 is long, procedurally intensive, and, as can be seen from the few decided cases, compliance with some of its sub-sections can be tricky. From case law, it is therefore important that, before a company proposes a transaction that may trigger an appraisal right, it should do its own due diligence on the risks of such a right being enforced by shareholders. The decision in the Sovereign case also provides a warning about the drafting of circulars and proposed resolutions. In respect of the circular, the following statement was made:

[74] That the December 2015 circular is confusing and misleading to say the least, is manifested in the different approaches taken and interpretations given by the three respective groups of litigants. ${ }^{150}$

Dealmakers involved in affected transactions should be alert to the type of disclosures required. In what may be regarded as a general warning that the effect of the proposed resolutions in some circulars is not adequately stated, the court in the Sovereign case indicated that:

\footnotetext{
It [the resolution to revoke the previous resolution passed] certainly does not comply with the requisites of clarity, specificity, sufficient information or explanatory material. It explains nothing at all, particularly to shareholders who have no clarity about their entitlement to vote at the meeting in the first place. ${ }^{151}$
}

For companies, it is clear that adherence to the procedures set out in the section cannot be over emphasised. Forewarned is forearmed. Similarly, it is important that shareholders intent on exercising their appraisal rights ensure that all of the procedures set out in the section are carefully adhered to. Provided that they have complied with the relevant requirements, minority shareholders are entitled to exercise their appraisal rights in terms of section 164 whenever companies undertake fundamental transactions. The appraisal right remedy does not deny the right of the majority to undertake fundamental transactions, provided that the relevant rules have been followed. The remedy seeks to balance the conflicting interests of the majority and minority shareholders.

\section{Bibliography}

\section{Literature}

Cassim "Shareholder Remedies and Minority Protection"

\begin{tabular}{ll}
\hline 150 & Sovereign para 74. \\
151 & Sovereign para 83.
\end{tabular}


Cassim MF "Shareholder Remedies and Minority Protection" in Cassim FHI (ed) Contemporary Company Law $2^{\text {nd }}$ ed (Juta Cape Town 2012) 755-825

Cilliers et al Corporate Law

Cilliers HS et al Corporate Law $2^{\text {nd }}$ ed (Butterworths Durban 1992)

Davids, Norwitz and Yuill 2010 Acta Juridica

Davids E, Norwitz T and Yuill D "A Microscopic Analysis of the New Merger and Amalgamation Provision in the Companies Act 71 of 2008" 2010 Acta Juridica 337-371

Latsky 2014 Stell LR

Latsky J "The Fundamental Transactions under the Companies Act: A Report Back from Practice after the First Few Years" 2014 Stell LR 361-384

Luiz 2012 PELJ

Luiz SM "Some Comments on the Scheme of Arrangement as an 'Affected Transaction' as Defined in the Companies Act 71 of 2008" 2012 PELJ 102131

Luiz 2014 SA Merc LJ

Luiz SM "Protection of Holders of Securities in the Offeree Regulated Company During Affected Transactions: General Offers and Schemes of Arrangements" 2014 SA Merc LJ 560-586

Mashabane 2016 De Rebus

Mashabane B "Appraisal Rights and Protection of Minority Shareholders" December 2016 De Rebus 30

Payne Takeovers in English and German Law

Payne J Takeovers in English and German Law (Hart Oxford 2002)

Seligson 2016 BTCLQ

Seligson M "Dissenting Minority Shareholders' Appraisal Rights" 2016 BTCLQ 1-12

Yeats 2014 Stell LR

Yeats JL "Putting Appraisal Rights in Perspective" 2014 Stell LR 328-342

Yeats Effective and Proper Exercise of Appraisal Rights

Yeats JL The Effective and Proper Exercise of Appraisal Rights Under the South African Companies Act, 2008: Developing a Strategic Approach through a Study of Comparable Foreign Law (DPhil-thesis University of Cape Town 2015) 
Yeats et al Commentary on the Companies Act

Yeats JL et al (eds) Commentary on the Companies Act of 2008 (Juta Cape Town 2018)

\section{Case law}

Cilliers v La Concorde Holdings Limited 2018 ZAWCHC 68 (14 June 2018) Juspoint Nominees (Pty) Ltd $v$ Sovereign Food Investments Limited (BNS Nominees (Pty) Ltd Intervening) 2016 ZAECPEHC 15 (26 April 2016)

Loest v Gendac (Pty) Ltd 2017 ZAGPPHC 73 (3 March 2017)

Standard Bank Nominees (RF) Proprietary Limited v Hospitality Property Fund Limited 2019 ZAGPJHC 263 (12 June 2019)

\section{Legislation}

Collective Investment Control Act 45 of 2002

Companies Act 61 of 1973

Companies Act 71 of 2008

Promotion of Access to Information Act 2 of 2000

\section{Government publications}

GN R48 in GG 999 of 12 January 1965 (Uniform Rules of Court)

GN R351 in GG 34239 of 26 April 2011 (Companies Regulations)

\section{Internet sources}

Hospitality Property Fund 2019 https://www.sharenet.co.za/v3/sens display.php?tdate $=20191121080000 \&$ seq $=8 \&$ scode $=/$

Hospitality Property Fund Limited 2019 Short-Form Unaudited Condensed Consolidated Financial Results for the Six Months Ended 30 September 2019 https://www.sharenet.co.za/v3/sens_display.php?tdate=201911 $21080000 \&$ seq $=8 \&$ scode $=/$ accessed 1 January 2020

Pick 'n Pay Stores 2016 https://www.picknpayinvestor.co.za/ downloads/investor-centre/circulars/2016/stores-limited-24-june-2016.pdf 
Pick 'n Pay Stores Limited 2016 Circular to Stores Shareholders https://www.picknpayinvestor.co.za/downloads/investorcentre/circulars/2016/stores-limited-24-june-2016.pdf accessed 1 January 2020

Pioneer Food Group 2019 https://pioneerfoods.co.za/2019/08/29/2430/ Pioneer Food Group 2019 Distribution of Circular Notice of General Meeting https://pioneerfoods.co.za/2019/08/29/2430/ accessed 4 February 2020

Trans Hex Group 2019 https:/www.transhex.co.za/wpcontent/uploads/2019/09/TRANS-HEX-Shareholder-CIRCULAR.pdf Trans Hex Group Limited 2019 Circular to Trans Hex Shareholders https://www.transhex.co.za/wp-content/uploads/2019/09/TRANS-HEXShareholder-CIRCULAR.pdf accessed 1 January 2020

TRP 2020 https://trpanel.co.za/financials/

Takeover Regulation Panel 2020 Annual Reports https://trpanel.co.za/financials/ accessed 20 January 2020

\section{List of Abbreviations}

$\begin{array}{ll}\text { BTCLQ } & \text { Business Tax and Company Law Quarterly } \\ \text { JSE } & \text { Johannesburg Stock Exchange } \\ \text { PAIA } & \text { Promotion of Access to Information Act } \\ \text { PELJ } & \text { Potchefstroom Electronic Law Journal } \\ \text { SA Merc LJ } & \text { South African Mercantile Law Journal } \\ \text { SAMVAL } & \text { South African Code for the Reporting of } \\ & \text { Mineral Asset Valuation } \\ \text { Stell LR } & \text { Stellenbosch Law Review } \\ \text { TRP } & \text { Takeover Regulation Panel }\end{array}$

